University of Nebraska - Lincoln

DigitalCommons@University of Nebraska - Lincoln

\title{
Simulation Supplements Field Studies to Determine No-Till Dryland Corn Population Recommendations for Semiarid Western Nebraska
}

\author{
Drew J. Lyon \\ University of Nebraska-Lincoln, drew.lyon@wsu.edu \\ Graeme L. Hammer \\ Agric. Prod. Syst. Res. Unit \\ Greg B. McLean \\ Agric. Prod. Syst. Res. Unit \\ Jurg M. Blumenthal \\ Panhandle Res. and Ext. Cent, 4502 Ave. I, Scottsbluff, NE
}

Follow this and additional works at: https://digitalcommons.unl.edu/panhandleresext

Part of the Agriculture Commons

Lyon, Drew J.; Hammer, Graeme L.; McLean, Greg B.; and Blumenthal, Jurg M., "Simulation Supplements Field Studies to Determine No-Till Dryland Corn Population Recommendations for Semiarid Western Nebraska" (2003). Panhandle Research and Extension Center. 9.

https://digitalcommons.unl.edu/panhandleresext/9

This Article is brought to you for free and open access by the Agricultural Research Division of IANR at DigitalCommons@University of Nebraska - Lincoln. It has been accepted for inclusion in Panhandle Research and Extension Center by an authorized administrator of DigitalCommons@University of Nebraska - Lincoln. 


\title{
MODELING
}

\section{Simulation Supplements Field Studies to Determine No-Till Dryland Corn Population Recommendations for Semiarid Western Nebraska}

\author{
Drew J. Lyon,* Graeme L. Hammer, Greg B. McLean, and Jürg M. Blumenthal
}

\begin{abstract}
In a 2-yr multiple-site field study conducted in western Nebraska during 1999 and 2000, optimum dryland corn (Zea mays L.) population varied from less than 1.7 to more than 5.6 plants $\mathrm{m}^{-2}$, depending largely on available water resources. The objective of this study was to use a modeling approach to investigate corn population recommendations for a wide range of seasonal variation. A corn growth simulation model (APSIM-maize) was coupled to long-term sequences of historical climatic data from western Nebraska to provide probabilistic estimates of dryland yield for a range of corn populations. Simulated populations ranged from 2 to 5 plants $\mathrm{m}^{-2}$. Simulations began with one of three levels of available soil water at planting, either 80, 160, or $240 \mathrm{~mm}$ in the surface $1.5 \mathrm{~m}$ of a loam soil. Gross margins were maximized at 3 plants $\mathrm{m}^{-2}$ when starting available water was 160 or $240 \mathrm{~mm}$, and the expected probability of a financial loss at this population was reduced from about $10 \%$ at $160 \mathrm{~mm}$ to $0 \%$ at $240 \mathrm{~mm}$. When starting available water was $80 \mathrm{~mm}$, average gross margins were less than $\$ 15 \mathrm{ha}^{-1}$, and risk of financial loss exceeded $\mathbf{4 0} \%$. Median yields were greatest when starting available soil water was $240 \mathrm{~mm}$. However, perhaps the greater benefit of additional soil water at planting was reduction in the risk of making a financial loss. Dryland corn growers in western Nebraska are advised to use a population of 3 plants $\mathbf{m}^{-2}$ as a base recommendation.
\end{abstract}

$\mathrm{W}$ ATER IS THE MOST LIMITING resource for dryland crop growth in the semiarid areas of the U.S. Great Plains (Smika, 1970). Summer fallow, the practice of controlling all plant growth during the noncrop season, is commonly used to stabilize winter wheat (Triticum aestivum L.) production in this region of high environmental variability. Wheat-fallow is the predominate cropping system in the Great Plains, but water storage efficiency during fallow is frequently less than $25 \%$ with conventional tillage (McGee et al., 1997). The advent of reduced- and no-till systems has generally enhanced the ability to capture and retain precipitation in the soil during noncrop periods of the cropping cycle, making it more feasible to reduce the frequency of fallow and intensify cropping systems relative to wheat-fallow (Peterson et al., 1996).

In the Great Plains, annual precipitation is concentrated during the warm season from April to September. Hence, inclusion of a summer crop, e.g., corn or grain sorghum [Sorghum bicolor (L.) Moench], in a 3-yr sys-

D.J. Lyon and J.M. Blumenthal, Panhandle Res. and Ext. Cent, 4502 Ave. I, Scottsbluff, NE 69361; and G.L. Hammer and G.B. McLean, Agric. Prod. Syst. Res. Unit, QDPI, PO Box 102, Toowoomba, QLD, Australia 4350. Journal Ser. no. 13756 of the Univ. of Nebraska Agric. Res. Div. Received 11 July 2002. *Corresponding author (DLYON1@ unl.edu).

Published in Agron. J. 95:884-891 (2003). tem of wheat-summer crop-fallow increased the efficient use of precipitation by reducing the frequency of summer fallow and using more water for crop transpiration (Farahani et al., 1998). In addition to increased precipitation use efficiency and grain yield, more intensified dryland cropping systems increase potentially active surface soil organic C and N (Peterson et al., 1998), effectively control winter annual grass weeds in winter wheat (Daugovish et al., 1999), and increase net return and reduce financial risk (Dhuyvetter et al., 1996).

Growers in the semiarid regions of western Nebraska have had limited experience with dryland corn. Before 1997, fewer than 3800 ha of dryland corn were planted each year in the western crop-reporting district. As more growers diversified and intensified their rotations, land planted to corn grew to more than 28700 ha in 1999 (NASS, 2000). Growers were getting conflicting population recommendations and requested assistance from the University of Nebraska.

Determining population response of corn is a recurrent area of study, with modern hybrids having greater tolerance of high plant density than older hybrids (Tollenaar, 1991). In one southwest Kansas study, dryland corn performed best when no-till-planted in early to mid-May at plant populations not exceeding 4.45 plants $\mathrm{m}^{-2}$ (Norwood and Currie, 1996). A more recent study from this same region achieved maximum yield and water use efficiency with a late May planting, combined with later-maturing hybrids and plant populations up to 6.0 plants $\mathrm{m}^{-2}$ (Norwood, 2001). However, in northwest Kansas, no yield differences were found for corn populations of 2.1, 2.47, and 3.71 plants $\mathrm{m}^{-2}$ (Havlin and Lamm, 1988). In a summary of research results from locations across the USA and Canada, corn grain yields leveled off but did not decrease above the optimum plant population, except in those fields with yield levels below 7500 $\mathrm{kg} \mathrm{ha}^{-1}$ (Paszkiewicz and Butzen, 2001).

Blumenthal et al. (2003) advised dryland corn growers to use a plant population of 2.7 plants $\mathrm{m}^{-2}$, based on $2 \mathrm{yr}$ of field research conducted at four locations each year. Unfortunately, summer precipitation was very different between the $2 \mathrm{yr}$ of the study, and often the treatment resulting in the greatest yield in $1 \mathrm{yr}$ provided the least yield in the other year. The standard analysisof-variance approach used in that study did not allow for a satisfactory assessment of the production risks associated with the various population treatments.

Crop modeling has been a developing component of agronomic research for more than $30 \mathrm{yr}$ (Sinclair and Seligman, 1996). Crop models have been successfully used to analyze management practice in regions where 
a highly variable environment results in increased riskiness of production decisions (Meinke et al., 1993; Muchow et al., 1994). The effects of plant population on corn yields were simulated for semiarid areas of eastern Kenya using CERES-Maize (Keating et al., 1990). The Agricultural Production Systems Simulator (APSIM) is a comprehensive cropping-systems modeling platform (Keating et al., 2003), which incorporates a generic crop model template (Wang et al., 2002) that underpins a broad range of crop models. Production risk analyses based on simulation studies using APSIM have been used to link research with change in management practices via various participatory methods (Hammer et al., 1996a; Nelson et al., 2002). The APSIM-maize model has been used to examine risks associated with viability of cropping in northern Australia (Carberry et al., 1996).

The objective of this study was to use a modeling approach to investigate corn population recommendations for a wide range in seasonal variation. A corn growth simulation model (APSIM-maize) was coupled with long-term sequences of historical climatic data to provide probabilistic estimates of dryland yield for a range of corn populations. The insights gained by this approach may be used to supplement the recommendations made by Blumenthal et al. (2003) for semiarid western Nebraska.

\section{MATERIALS AND METHODS}

Experimental data from corn population by $\mathrm{N}$ rate field studies, conducted at the High Plains Agricultural Laboratory near Sidney, NE $\left(41^{\circ} 12^{\prime} \mathrm{N}, 103^{\circ} 0^{\prime} \mathrm{W}\right.$ ), in 1999 and 2000 (Blu-

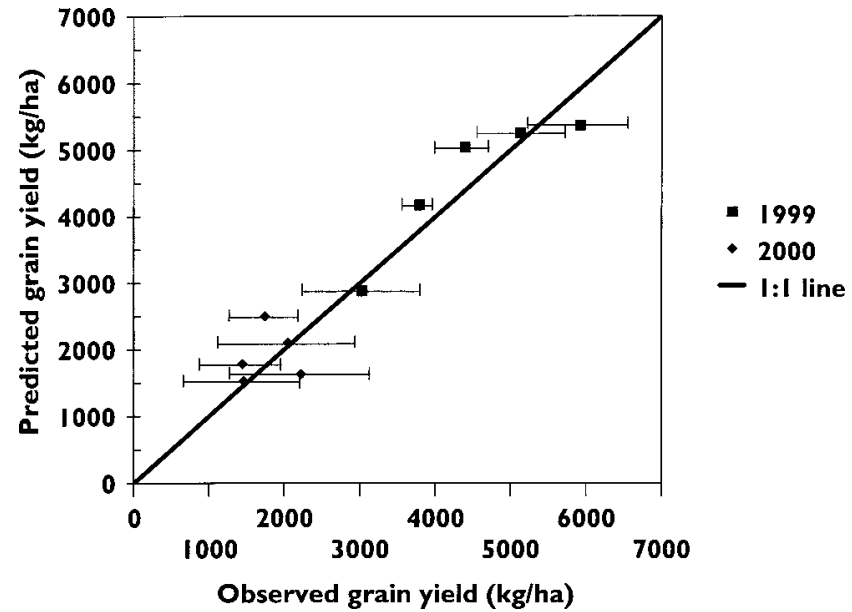

Fig. 1. Observed vs. predicted corn grain yields at Sidney, NE, in 1999 and 2000. A N supply of $125 \mathrm{~kg} \mathrm{ha}^{-1}$ was used for the simulation, which was similar to the $N$ available in the zero $N$ rate treatment from the 1999 and 2000 field studies. Bars indicate \pm 1 standard deviation from the mean.

menthal et al., 2003) were used to validate the crop model. Seasonal precipitation in 1999 was near the 50-yr average for Sidney, but precipitation from flowering through early grain fill (mid-July through August) was in the top $20 \%$ of years. The 2000 season was extremely dry, with only one season in the previous $50 \mathrm{yr}$ being drier. Average monthly temperatures were near normal for both growing seasons. Climatic data for the other sites in the study were collected at the nearest automated weather stations, which were as much as $30 \mathrm{~km}$ from a given study site. These data, particularly the precipitation data, were deemed to be insufficiently representative to allow for their use in model validation.

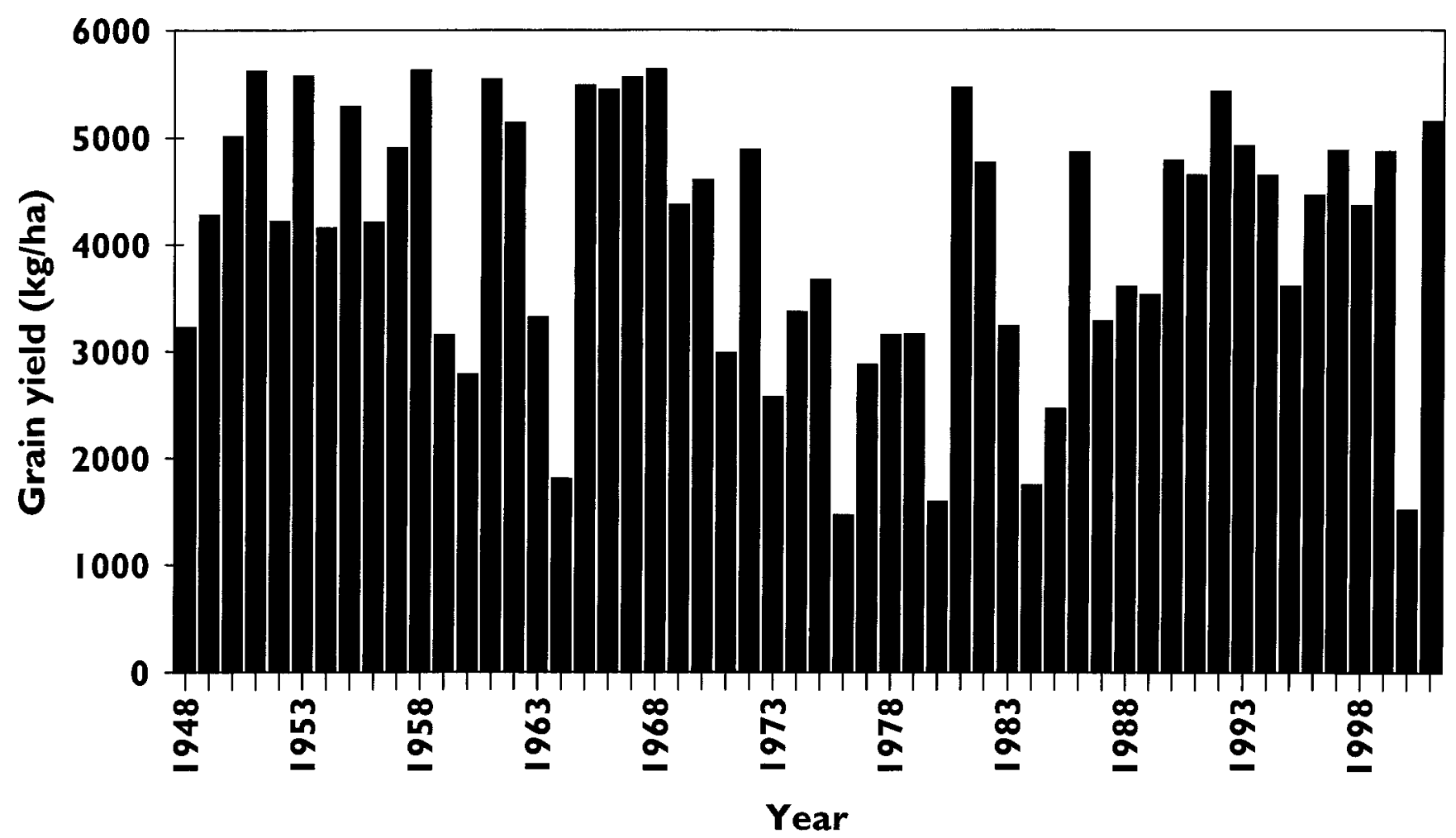

Fig. 2. Simulated corn yield for the $54 \mathrm{yr}$ of historical climate record at Sidney, NE, for a crop planted at a population of 3 plants $\mathrm{m}^{-2}$ each year on 5 May with $160 \mathrm{~mm}$ of available soil water and $125 \mathrm{~kg} \mathrm{~N} \mathrm{ha}^{-1}$. 
The model required input data on soil characteristics, crop management, and cultivar attributes such as maturity. Details on inputs for relevant soil and crop modules have been reported by Keating et al. (2003). Soil parameters to be used with APSIM were obtained for a Duroc loam (fine-silty, mixed, superactive, mesic Pachic Haplustoll) from the Cheyenne County Soil Survey (USDA-NRCS, 1997). Drained upper limits and lower limits for each depth increment were set, within the limits of the soil, to best simulate results from 1999. These same values were then tested against the 2000 field data and found to provide an acceptable simulation. Similarly, input specifications for crop maturity were fitted to results from 1999 and then tested against the 2000 field data.

Once tested, the APSIM-maize model was run using longterm climatic data and a range of planting densities. Daily temperature and precipitation data were available for Sidney and North Platte $\left(41^{\circ} 7^{\prime} \mathrm{N}, 100^{\circ} 40^{\prime} \mathrm{W}\right)$, NE, for $54 \mathrm{yr}$ and for Harrisburg $\left(41^{\circ} 37^{\prime} \mathrm{N}, 103^{\circ} 57^{\prime} \mathrm{W}\right)$, NE, for 92 yr. Daily radiation data were only available for $20 \mathrm{yr}$ at Sidney. Long-term daily radiation data, where missing, were generated with RadEst 3.00 software using the Campbell-Donatelli model (Donatelli et al., 2003). The simulations were conducted for an early maturing cultivar with phenology characteristics similar to 'Pioneer 3893', the cultivar used in the field studies by Blumenthal et al. (2003). Corn crops were simulated at established plant populations of 2, 3, 4, and 5 plants $\mathrm{m}^{-2}$. Simulations were started 5 May of each year when corn was planted into $4000 \mathrm{~kg} \mathrm{ha}^{-1}$ wheat residue. Grain yields were output at a $150 \mathrm{~g} \mathrm{~kg}^{-1}$ moisture content basis.

The predominant loam and silt loam soils of western $\mathrm{Ne}$ braska have an available water capacity of about $240 \mathrm{~mm}$ in the top $1.5 \mathrm{~m}$ (USDA-NRCS, 1997). To examine the effect of soil water availability at planting on yield, the simulations were begun with either 80,160 , or $240 \mathrm{~mm}$ of soil water. These soil water conditions were reset each year of the simulations so that starting conditions were identical each year. Beginning soil $\mathrm{N}$ was set at $125 \mathrm{~kg} \mathrm{~N}^{-1}$ each year. Blumenthal et al. (2003) found this supply of $\mathrm{N}$ was needed to obtain $95 \%$ of maximum dryland corn yields in western Nebraska.

Profit was calculated as the product of yield and price less costs. Costs that did not vary by treatment were set at $\$ 165.27$ $\mathrm{ha}^{-1}$ and included costs such as labor, management, fertilizer, herbicides, machinery use, harvesting, taxes, and depreciation (Selley et al., 2001). Land costs varied by location and were set at $\$ 49.40, \$ 54.34$, and $\$ 71.63 \mathrm{ha}^{-1}$ for Harrisburg, Sidney, and North Platte, respectively. Costs that varied by treatment were seed, set at $\$ 4.40 \mathrm{~kg}^{-1}$, and grain-hauling charges of $\$ 5.11 \mathrm{t}^{-1}$. Grain price was set at the 5-yr (1997-2001) average corn price in western Nebraska of $\$ 83.68 \mathrm{t}^{-1}$. For each population, average profit was calculated for each year of the simulation at each of the three sites. The economic risk associated with each population was determined as the percentage of years recording a loss, i.e., profit was less than zero. The tradeoff between profit and economic risk was used as a means

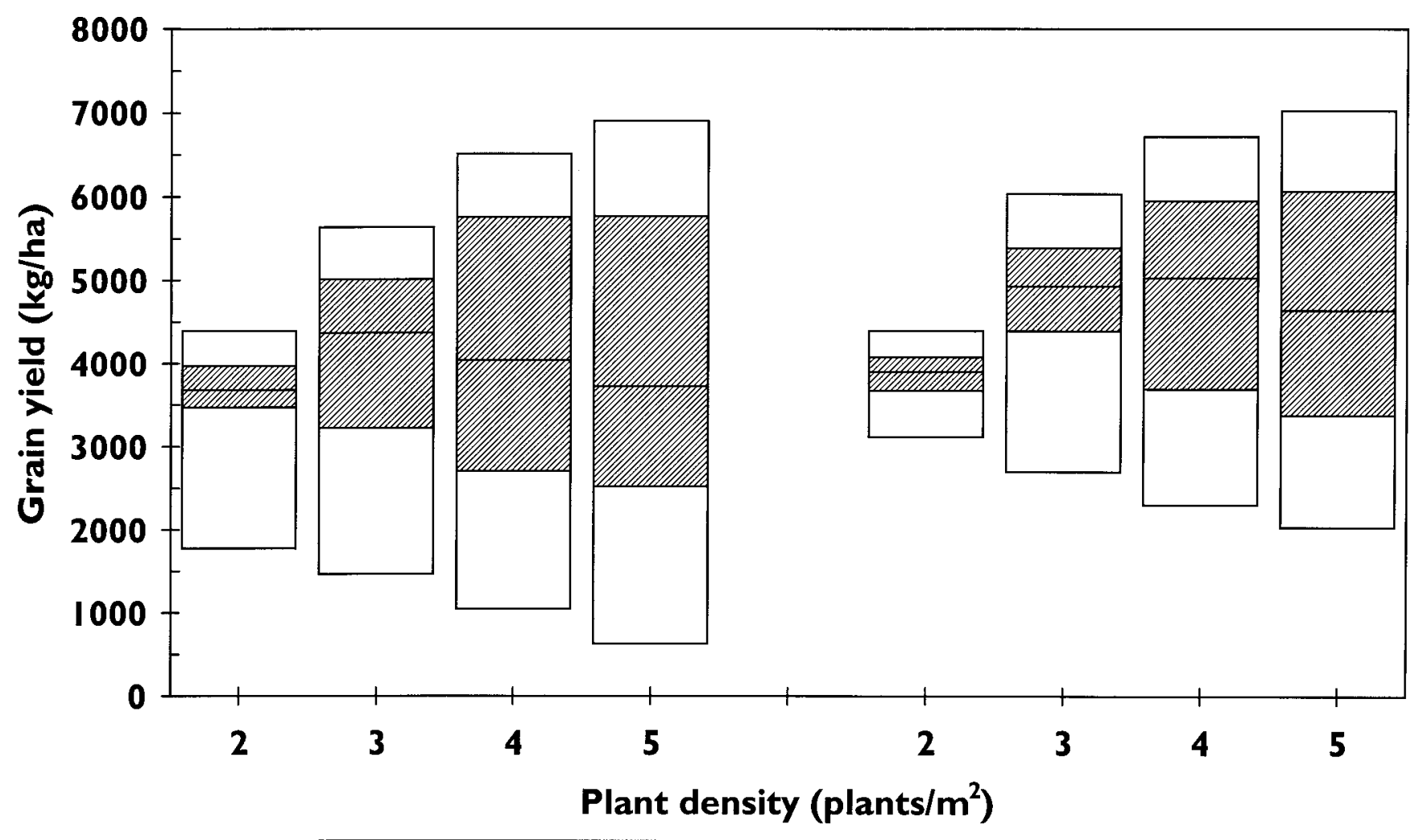

160

\section{Available soil water at planting $(\mathrm{mm})$}

Fig. 3. Simulated corn yield ranges for the $54 \mathrm{yr}$ of historical climate record at Sidney, NE, given different populations and different quantities of available soil water at planting. Extremes on each bar encompass the range between minimum and maximum values, extremes of the hatched section of each bar encompass the range between the 25 and $75 \%$ quartiles, and the horizontal line within each hatched section shows the median. 
to compare population management options as reported by Hammer et al. (1996b) for wheat in Australia.

\section{RESULTS AND DISCUSSION}

Simulated grain yields were compared with observed yields. The effect of population on yield at any given $\mathrm{N}$ rate was adequately simulated by the model. Figure 1 shows the relationship between observed and predicted values with no applied N. Similar relationships were observed for the other four $\mathrm{N}$ rate treatments. Residual soil $\mathrm{NO}_{3}$ in the surface $1.5 \mathrm{~m}$ of soil before planting was between 120 and $130 \mathrm{~kg} \mathrm{ha}^{-1}$ at Sidney in 1999 and 2000. This quantity of initial $\mathrm{N}$ limited the response of corn to applied $\mathrm{N}$, making it impossible to test simulation of $\mathrm{N}$ response on these $2 \mathrm{yr}$ of experimental data. Nonetheless, $\mathrm{N}$ was added at $125 \mathrm{~kg} \mathrm{~N} \mathrm{ha}^{-1}$ at planting for the simulation study to ensure $\mathrm{N}$ was nonlimiting in all years simulated.

The 54-yr time series of simulated yield for Sidney with $160 \mathrm{~mm}$ available soil water at planting and a population of 3 plants $\mathrm{m}^{-2}$ demonstrates the variability associated with dryland corn production in semiarid western Nebraska (Fig. 2). Yields greater than $5500 \mathrm{~kg} \mathrm{ha}^{-1}$ were attained in the best years, whereas in the worst years, yields did not exceed $2000 \mathrm{~kg} \mathrm{ha}^{-1}$.

Available soil water at planting influenced the yield response of corn to population (Fig. 3). At Sidney, with $160 \mathrm{~mm}$ of available soil water at planting, maximum median yield was $4370 \mathrm{~kg} \mathrm{ha}^{-1}$ and was achieved at a population of 3 plants $\mathrm{m}^{-2}$. However, with a full soil water profile containing $240 \mathrm{~mm}$ of available soil water at planting, maximum median yield was $5030 \mathrm{~kg} \mathrm{ha}^{-1}$ and was achieved at a population of 4 plants $\mathrm{m}^{-2}$. At any given quantity of initial available soil water, the effect of increasing population from 2 to 5 plants $\mathrm{m}^{-2}$ was to increase the variability in yield outcomes over time, in other words, to increase production risk. Although median yield was increased at all populations as available soil water at planting was increased from 160 to $240 \mathrm{~mm}$, perhaps the greater effect of increased water supply at planting was to reduce production risk (Fig. 3).

Average profits at Sidney were maximized at 3 plants $\mathrm{m}^{-2}$, with profits of $\$ 127.04$ and $\$ 181.13 \mathrm{ha}^{-1}$ when available soil water at planting was 160 or $240 \mathrm{~mm}$, respectively (Fig. 4). In addition to maximizing average profits at a population of 3 plants $\mathrm{m}^{-2}$, the number of years in which financial loss occurred, i.e., the risk of loss, was less at this population than at greater populations. Growers are likely to accept the very small increase in risk of loss that occurred as population was increased from 2 to 3 plants $\mathrm{m}^{-2}$ to capture increased average profits of about $\$ 24.58$ and $\$ 58.98 \mathrm{ha}^{-1}$ at 160 and $240 \mathrm{~mm}$ of available soil water at planting, respectively (Fig. 4). With $80 \mathrm{~mm}$ of available water at planting, maximum average profit was $\$ 14.98 \mathrm{ha}^{-1}$ at 2 plants $\mathrm{m}^{-2}$. The risk of a financial loss was $43 \%$. Hence, planting corn when available soil water at planting is $\leq 80 \mathrm{~mm}$ is not advisable.

In western Nebraska, average precipitation declines from east to west. This is caused by the rain shadow

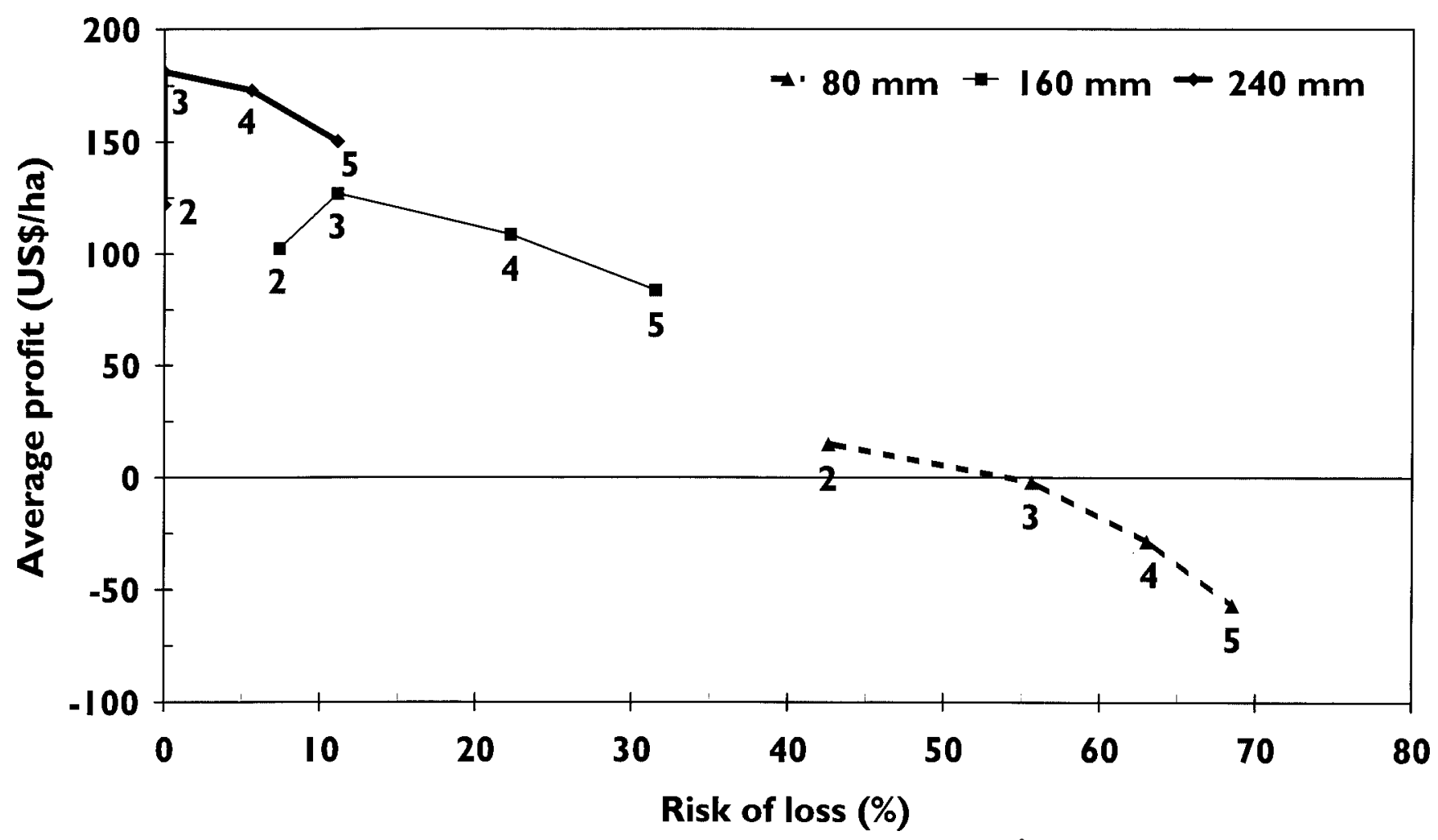

Fig. 4. Average profit vs. risk of making a loss for a range of fixed corn populations $\left(2-5\right.$ plants $\left.\mathrm{m}^{-2}\right)$ and quantities of available soil water at planting. Profit and risk data were derived from simulated corn yields for the $54 \mathrm{yr}$ of historical climate record at Sidney, NE. 


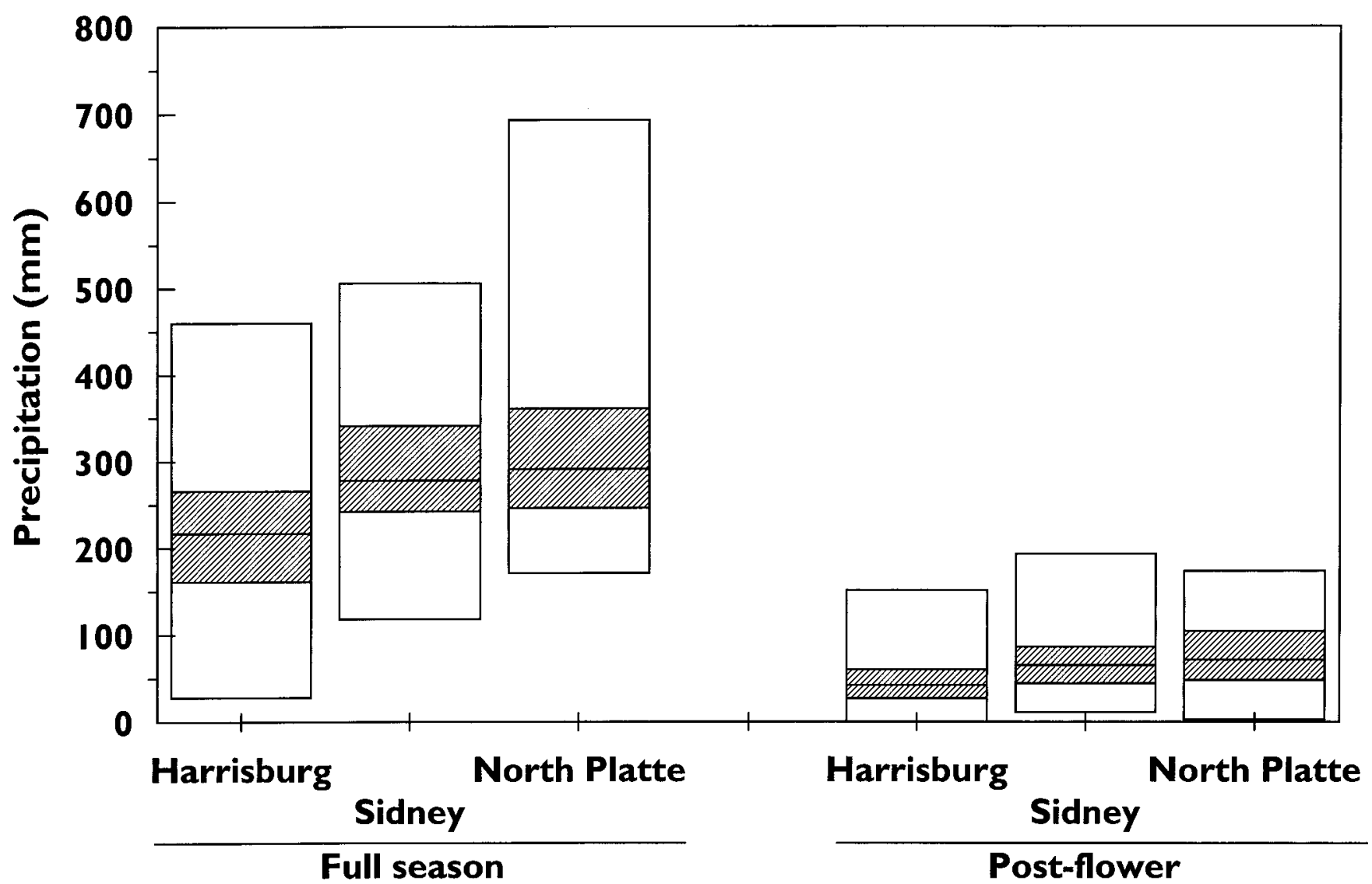

Fig. 5. Precipitation ranges for full-season (planting through harvest) and postflower (flowering through harvest) periods using the 54 yr of historical climate record at Sidney and North Platte, NE, and the 92-yr record at Harrisburg, NE. Extremes on each bar encompass the range between minimum and maximum values, extremes of the hatched section of each bar encompass the range between the 25 and $75 \%$ quartiles, and the horizontal line within each hatched section shows the median.

effect of the Rocky Mountains where elevations exceed $4200 \mathrm{~m}$. The effect of summer precipitation on population recommendations was investigated by using longterm historical climate data from Harrisburg, Sidney, and North Platte, NE. Full-season (planting to physiological maturity) precipitation averaged 216, 283, and $317 \mathrm{~mm}$ at Harrisburg, Sidney, and North Platte, respectively (Fig. 5). Postflower (flowering to physiological maturity) precipitation at these three sites averaged 48 , 67 , and $78 \mathrm{~mm}$, respectively. In general, average profit was reduced and risk of loss increased from North Platte in the east to Harrisburg in the west (Fig. 6).

At North Platte, with available soil water at planting of $160 \mathrm{~mm}$, average profit was maximized at $\$ 177.70$ $\mathrm{ha}^{-1}$ with a population of 4 plants $\mathrm{m}^{-2}$. Risk of loss was $4 \%$. At Sidney, 3 plants $\mathrm{m}^{-2}$ maximized average profit at $\$ 127.04 \mathrm{ha}^{-1}$ with an $11 \%$ risk of economic loss. Average profit was maximized at Harrisburg at $\$ 83.74$ with a population of 2 plants $\mathrm{m}^{-2}$. As previously discussed for Sidney, median yields increased and risk of economic loss decreased at all locations as soil water at planting increased. With $240 \mathrm{~mm}$ of available soil water at planting, average profits were maximized at Harrisburg, Sidney, and North Platte at populations of 3, 3, and 4 plants $\mathrm{ha}^{-1}$, respectively. When available soil water at planting was $80 \mathrm{~mm}$, average profits at Harrisburg were negative at all populations, and risk of loss exceeded $73 \%$. At North Platte, average profits were maximized at $\$ 55.84$ $\mathrm{ha}^{-1}$ with 3 plants $\mathrm{ha}^{-1}$, but risk of economic loss was $32 \%$. Planting corn when soil water at planting is $\leq 80 \mathrm{~mm}$ is not advised at any of the sites in this study.

Using data from seven site-year combinations collected in 1999 and 2000, Blumenthal et al. (2003) advised western Nebraska corn growers to use a population of 2.7 plants $\mathrm{m}^{-2}$. However, in this semiarid environment, with its high rainfall variability, seven site-year combinations do not provide sufficient information to assess the effect that management decisions have on production and economic risks. Coupling a crop growth simulation model to long-term sequences of climatic data provides probabilistic estimates of yield for a range of seasons and is a good way to supplement findings from shortterm field studies (Muchow et al., 1994). Although the use of this approach has not resulted in a distinctly different population recommendation than made by Blumenthal et al. (2003), it has provided a more complete understanding of the risks associated with the plant population decision. It has also highlighted the importance of knowing the amount of available soil water at planting when making the decision about population.

Growers who have only recently incorporated corn into their dryland rotations have tended to use a popula- 


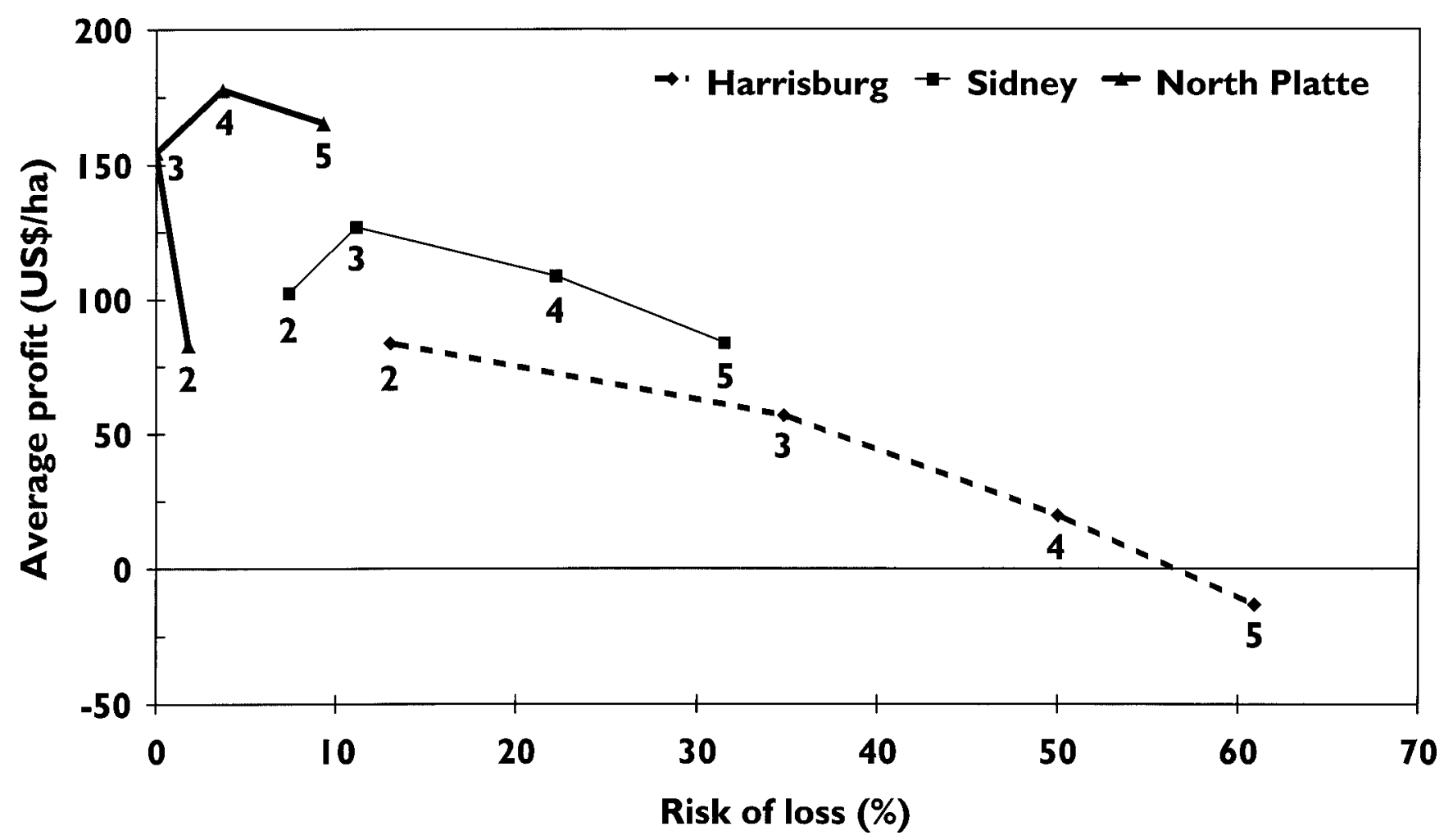

Fig. 6. Average profit vs. risk of making a loss for a range of fixed corn populations (2-5 plants $\left.\mathrm{m}^{-2}\right)$ with $160 \mathrm{~mm}$ of available soil water at planting. Profit and risk data were derived from simulated corn yields for the $54 \mathrm{yr}$ of historical climate record at Sidney and North Platte, NE, and the 92-yr record at Harrisburg, NE.

tion around 4 plants $\mathrm{m}^{-2}$, whereas earlier recommendations for the area were 3 plants $\mathrm{m}^{-2}$ or less (R.N. Klein, personal communication, 2002). The decision to use greater populations has been based on information developed in northeast Colorado during the 1990s and on recommendations made by many commercial seed dealers. Growers know their yields may be reduced by using greater populations in dry years compared with lower populations, but many of them feel that this is more than compensated for by greater yields in the years with wet summers. This hypothesis appears to have merit when the difference in simulated gross margins at 3 and 4 plants $\mathrm{m}^{-2}$ are compared for Sidney during the period from 1991 through 2001 (Fig. 7). However, during the 1970s and 1980s, the additional risk of a loss from using a population of 4 plants $\mathrm{m}^{-2}$ was rarely rewarded with increased profits relative to the lower population. This highlights another benefit of supplementing field research, which is seldom conducted for more than 2 to $5 \mathrm{yr}$, with a simulation modeling approach. The central United States has distinct interdecadal variations in annual precipitation ( $\mathrm{Hu}$ et al., 1998). Field research may be biased by the period of time in which it was conducted. Coupling a crop growth simulation model to long-term sequences of climate data can identify this bias and allow for the appropriate adjustment of recommendations.

Selection of the appropriate population for any given year could be greatly enhanced by access to skillful seasonal forecasts. The Southern Oscillation Index phase system (Stone and Auliciems, 1992; CINRS, 2002) has shown promise for use in tactical management of crops in northeastern Australia, a region of extremely variable climate (Hammer et al., 1996b.). However, use of the Southern Oscillation Index phase system did not appear to provide significant skill for forecasting in western Nebraska (data not shown). This lack of skill may be due to variability in the intensity of the teleconnection of the El Niño-Southen Oscillation with summer rainfall in the central United States (Hu and Feng, 2001). With improvement in skill of seasonal forecasts in the central United States, it may be feasible to alter corn population to fit a specific seasonal forecast. Until that time, however, no-till dryland corn growers in western Nebraska are advised to use a population of 3 plants $\mathrm{m}^{-2}$ as a base recommendation. Adjustments to this base recommendation of about \pm 1 plant $\mathrm{m}^{-2}$ may be made in response to available soil water at planting; amount and quality of crop residue; changes in corn and/or seed prices; average seasonal precipitation relative to Sidney, $\mathrm{NE}$; and the grower's attitude to risk. The estimates of yield probabilities presented in this paper can help dryland corn growers in semiarid regions of western Nebraska with this decision-making process.

\section{ACKNOWLEDGMENTS}

The senior author thanks the many members of the Agricultural Production Systems Research Unit (APSRU) who assisted him in a myriad of ways during his professional development leave to Toowoomba, QLD, Australia. 


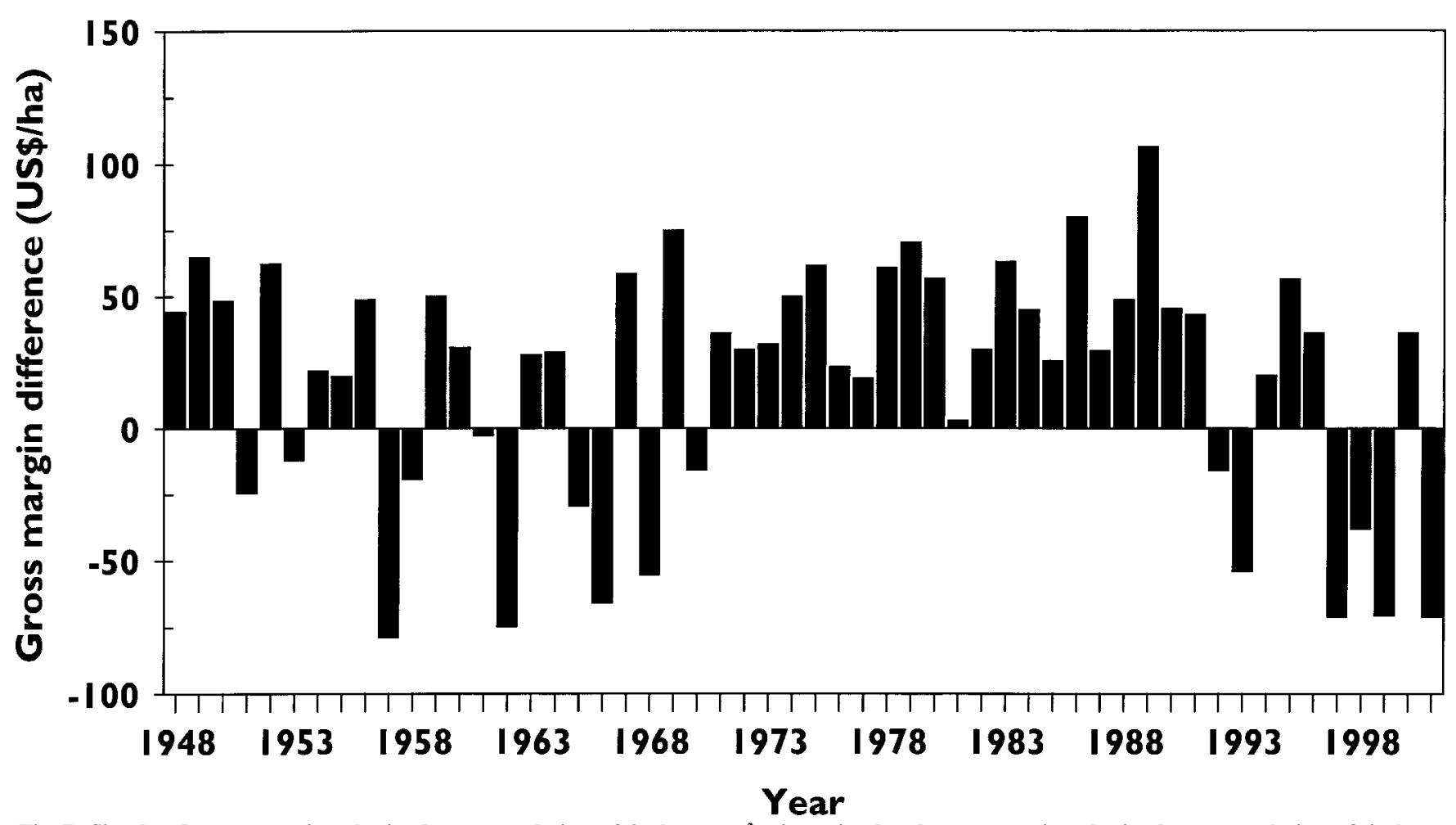

Fig. 7. Simulated gross margins obtained at a population of 3 plants $\mathbf{m}^{-2}$ minus simulated gross margins obtained at a population of 4 plants $\mathrm{m}^{-2}$ for a crop planted each year on 5 May with $160 \mathrm{~mm}$ available soil water and $125 \mathrm{~kg}^{\mathrm{N}} \mathrm{ha}^{-1}$ and for the $54-\mathrm{yr}$ record of historical climate record at Sidney, NE.

\section{REFERENCES}

Blumenthal, J.M., D.J. Lyon, and W.W. Stroup. 2003. Optimal plant population and nitrogen fertility for dryland corn in western $\mathrm{Ne}$ braska. Agron. J. 95:(this issue).

Carberry, P.S., R.L. McCown, R.C. Muchow, J.P. Dimes, M.E. Probert, P.L. Poul, and N.P. Dalgleish. 1996. Simulation of a legume ley farming system in northern Australia using the Agricultural Production Systems Simulator. Aust. J. Exp. Agric. 36:1037-1048.

[CINRS] Climate Impacts and Natural Resource Systems group. 2002. Seasonal climate outlook [Online]. Available at http://www. longpaddock.qld.gov.au (verified 28 Mar. 2003). CINRS group, Nat. Resour. Sci., Queensland Dep. of Nat. Resour. and Mines, Indooroopilly, QLD, Australia.

Daugovish, O., D.J. Lyon, and D.D. Baltensperger. 1999. Cropping systems to control winter annual grasses in winter wheat (Triticum aestivum). Weed Technol. 13:120-126.

Dhuyvetter, K.C., C.R. Thompson, C.A. Norwood, and A.D. Halvorson. 1996. Economics of dryland cropping systems in the Great Plains: A review. J. Prod. Agric. 9:216-222.

Donatelli, M., G. Bellocchi, and F. Fontana. 2003. RadEst 3.00: Software to estimate daily radiation data from commonly available meteorological variables. Eur. J. Agron. 18:363-367.

Farahani, H.J., G.A. Peterson, D.G. Westfall, L.A. Sherrod, and L.R. Ahuja. 1998. Soil water storage in dryland cropping systems: The significance of cropping intensification. Soil Sci. Soc. Am. J. 62: 984-991.

Hammer, G.L., S.C. Chapman, and R.C. Muchow. 1996a. Modelling sorghum in Australia: The state of the science and its role in the pursuit of improved practices. p. 43-61. In M.A. Foale et al. (ed.) Proc. Australian Sorghum Conf., 3rd, Tamworth, NSW. 20-22 Feb. 1996. Occasional Publ. 93. Australian Inst. of Agric. Sci., Melbourne, VIC.

Hammer, G.L., D.P. Holzworth, and R. Stone. 1996b. The value of skill in seasonal climate forecasting to wheat crop management in a region with high climatic variability. Aust. J. Agric. Res. 47:717-737.

Havlin, J.L., and F.R. Lamm. 1988. Management of dryland corn for the central Great Plains. p. 837-838. In P.W. Unger et al. (ed.) Challenges in dryland agriculture - a global perspective. Proc. Int. Conf. on Dryland Farming, Amarillo, TX. 15-17 Aug. 1988. Texas Agric. Exp. Stn., College Station.

$\mathrm{Hu}$, Q., and S. Feng. 2001. Variations of teleconnection of ENSO and interannual variation in summer rainfall in the central United States. J. Clim. 14:2469-2480.

Hu, Q., C.M. Woodruff, and S.E. Mudrick. 1998. Interdecadal variations of annual precipitation in the central United States. Bull. Am. Meteorol. Soc. 79:221-229.

Keating, B.A., P.S. Carberry, G.L. Hammer, M.E. Probert, M.J. Robertson, D. Holzworth, N.I. Huth, J.N.G. Hargreaves, H. Meinke, Z. Hochman, G. McLean, K. Verburg, V. Snow, J.P. Dimes, M. Silburn, E. Wang, S. Brown, K.L. Bristow, S. Asseng, S. Chapman, R.L. McCown, D.M. Freebairn, and C.J. Smith. 2003. An overview of APSIM, a model designed for farming systems simulation. Eur. J. Agron. 18:267-288.

Keating, B.A., B.M. Wafula, and R.L. McCown. 1990. Simulation of plant density effects on maize yield as influenced by water and nitrogen limitations. p. 547-559. In Proc. Int. Congr. on Plant Physiol., New Delhi, India. 15-20 Feb. 1988. Soc. for Plant Physiol. and Biochem., New Delhi.

McGee, E.A., G.A. Peterson, and D.G. Westfall. 1997. Water storage efficiency in no-till dryland cropping systems. J. Soil Water Conserv. 52:131-136.

Meinke, H., G.L. Hammer, and S.C. Chapman. 1993. A sunflower simulation model: II. Simulating production risks in a variable subtropical environment. Agron. J. 85:735-742.

Muchow, R.C., G.L. Hammer, and R.L. Vanderlip. 1994. Assessing climatic risk to sorghum production in water-limited subtropical environments: II. Effects of planting date, soil water at planting, and cultivar phenology. Field Crops Res. 36:235-246.

[NASS] Nebraska Agricultural Statistics Service. 2000. 1999-2000 Nebraska agricultural statistics. NASS, Lincoln, NE.

Nelson, R.A., D.P. Holzworth, G.L. Hammer, and P.T. Hayman. 2002. Infusing the use of seasonal climate forecasting into crop 
management in North East Australia using discussion support software. Agric. Syst. 74:393-414.

Norwood, C.A. 2001. Planting date, hybrid maturity, and plant population effects on soil water depletion, water use, and yield of dryland corn. Agron. J. 93:1034-1042.

Norwood, C.A., and R.S. Currie. 1996. Tillage, planting date, and plant population effects on dryland corn. J. Prod. Agric. 9:119-122.

Paszkiewicz, S., and S. Butzen. 2001. Corn hybrid response to plant population. Crop Insights 11(6):1-5. Pioneer Hi-Bred Int., Johnston, IA.

Peterson, G.A., A.D. Halvorson, J.L. Havlin, O.R. Jones, D.J. Lyon, and D.L. Tanaka. 1998. Reduced tillage and increasing cropping intensity in the Great Plains conserves soil C. Soil Tillage Res. 47:207-218.

Peterson, G.A., A.J. Schlegel, D.L. Tanaka, and D.R. Jones. 1996. Precipitation use efficiency as affected by cropping and tillage systems. J. Prod. Agric. 9:180-186.
Selley, R.A., T.N. Barrett, R.T. Clark, R.N. Klein, and S.R. Melvin. 2001. Nebraska crop budgets. Nebraska Coop. Ext. EC01-872-S. Univ. of Nebraska, Lincoln.

Sinclair, T.R., and N.G. Seligman. 1996. Crop modeling: From infancy to maturity. Agron. J. 88:698-703.

Smika, D.E. 1970. Summer fallow for dryland winter wheat in the semiarid Great Plains. Agron. J. 62:15-17.

Stone, R.C., and A. Auliciems. 1992. SOI phase relationships with rainfall in eastern Australia. Int. J. Climatol. 12:625-636.

Tollenaar, M. 1991. Physiological basis of genetic improvement of maize hybrids in Ontario from 1959 to 1988. Crop Sci. 31:119-124.

[USDA-NRCS] U.S. Department of Agriculture-Natural Resources Conservation Service. 1997. Soil Survey of Cheyenne County, Nebraska. U.S. Gov. Print. Office, Washington, DC.

Wang, E., M.J. Robertson, G.L. Hammer, P.S. Carberry, D. Holzworth, H. Meinke, S.C. Chapman, J.N.G. Hargreaves, N.I. Huth, and G. McLean. 2002. Development of a generic crop model template in the cropping system model APSIM. Eur. J. Agron. 18:121-140. 